\title{
Purification and Substrate Specificity of endo-Type Inulinase from Penicillium purpurogenum
}

\author{
Shuichi ONODERA and Norio SHIOMI* \\ Department of Food Science, Faculty of Dairy Science, \\ Rakuno Gakuen University, Ebetsu, \\ Hokkaido 069, Japan \\ Received May 12, 1988
}

\begin{abstract}
An inulinase was highly purified from the culture broth of Penicillium purpurogenum by chromatographies on DEAE-Sepharose CL-6B, Toyopearl HW-65, and Bio-Gel P-100. The enzyme was homogeneous by disc electrophoretic analysis. The molecular weight was $6.4 \times 10^{4}$ by SDS-disc electrophoresis and gel filtration on Bio-Gel P-150. The isoelectric point was $\mathrm{pH} 3.6$ by isoelectric focusing. The enzyme hydrolyzed inulin rapidly, but did not affect sucrose. By paper chromatography analysis, the major products from inulin were tri-, tetra-, penta-, and hexasaccharides. The substrate specificity of the enzyme on hydrolyses of fructo-oligosaccharides $\left[1^{\mathrm{F}}(1-\right.$ $\beta$-D-fructofuranosyl) sucrose $(n=1$ to 6 and $\bar{n}$ (average of polymerization degree) $=8)$ ] were examined. The $K m$ values and relative maximum velocities for the hydrolyses of inulin and fructooligosaccharides $\left(\mathrm{GF}_{n}, n=2\right.$ to 7 and $\left.\bar{n}=9\right)$ were as follows: inulin, $(\overline{\mathrm{DP}}=35) 0.21 \mathrm{~mm}$ and 100 ; $\mathrm{GF}_{\overline{9}}, 0.24 \mathrm{~mm}$ and $86.5 ; \mathrm{GF}_{7}, 0.33 \mathrm{~mm}$ and $132 ; \mathrm{GF}_{6}, 0.85 \mathrm{~mm}$ and $71.2 ; \mathrm{GF}_{5}, 3.8 \mathrm{~mm}$ and $25.4 ; \mathrm{GF}_{4}$, $2.8 \mathrm{~mm}$ and 28.8; $\mathrm{GF}_{3}$, (nystose) $16 \mathrm{~mm}$ and $0.8 ; \mathrm{GF}_{2}$ (1-kestose), $8.4 \mathrm{~mm}$ and 0.2 . The molecular activities for the hydrolyses of fructo-oligosaccharides $\left(\mathrm{GF}_{n}, n=2\right.$ to 6$)$ were increased depending on the degree of polymerization of fructosyl residues, and were nearly constant if the polymerization degree was over seven. These results strongly suggested that the endo-type inulinase from Penicillium purpurogenum had a subsite structure consisting of at least seven subsites.
\end{abstract}

In studies of fructan metabolism, we have reported the structures of fructo-oligosaccharides $^{1 \sim 3)}$ and the properties of three kinds of fructosyltransferases ${ }^{4-7)}$ involved in the synthesis of the saccharides in asparagus root and onion bulbs, and have studied fructose-oligomer and -polymer hydrolyzing enzymes. Recently, we obtained endo- and exotype inulinases from a strain of Penicillium purpurogenum. ${ }^{8,9)}$ Inulinase $[2,1-\beta$-D-fructan fructanohydrolase $\mathrm{EC}$ 3.2.1.7] is known to catalyze the hydrolysis of $2,1-\beta$-D-fructosidic linkages in inulin, and has been found in higher plants ${ }^{10 \sim 12)}$ and microorganisms. ${ }^{13 \sim 16)}$ Inulinases from higher plants hydrolyze inulin and produce fructose, but do not hydrolyze sucrose. A number of inulinases from microorganisms also attacked inulin exo-wise, and affected sucrose.

* To whom correspondence should be addressed.
Nakamura et al. ${ }^{1718)}$ reported the properties of inulinases from Aspergillus niger and Penicillium sp. and that one of the extracellular inulinases from Aspergillus niger-12 ${ }^{17)}$ did not hydrolyze sucrose or raffinose, and attacked inulin endo-wise producing inulo-oligosaccharides. The products from inulin hydrolyzed by inulinase from Aspergillus niger-12 were identified by paper chromatography analysis.

However, few studies on the kinetics of inulinases were reported and the reaction mode of the enzymes was not investigated in detail. To find the reaction mode of inulinases, we intend to study the kinetic properties of the enzymes. In this paper, we describe the purification and substrate specificity of the endotype inulinase from Penicillium purpurogenum. 


\section{MATERIALS AND METHODS}

Microorganisms. Penicillium purpurogenum var. rubrisclerotium (HOK-1, FERM P-8705) ${ }^{19}$ obtained from soil (kindly supplied by Mitsui Toatsu Chemical Co., Ltd.) was aerobically cultivated with shaking at $28^{\circ} \mathrm{C}$ for 2 days in a medium of $2 \%$ inulin, $0.5 \%$ maltose, $0.5 \%$ $\mathrm{NH}_{4} \mathrm{H}_{2} \mathrm{PO}_{4}, 0.5 \% \mathrm{KH}_{2} \mathrm{PO}_{4}, 0.02 \%$ Tween 80 , and $0.05 \%$ $\mathrm{MgSO}_{4} \cdot 7 \mathrm{H}_{2} \mathrm{O}$. The culture $(125 \mathrm{ml})$ was inoculated into a jar fermenter containing $2.5 \mathrm{I}$ of the same medium. The mold was cultivated aerobically at $28^{\circ} \mathrm{C}$ for 3 days. The mycelia were removed by centrifugation and the supernatant was used as the crude enzyme solution.

Chemicals. Inulin and sucrose were purchased from Wako Pure Chemical Ind., Ltd. Fructo-oligosaccharides, identified as $1^{\mathrm{F}}(1-\beta \text {-D-fructofuranosyl })_{n}$ sucrose $(n=1$ to 6 , and $\bar{n}=8$ ) were isolated from roots of asparagus. ${ }^{1)}$

DEAE-Toyopearl, Toyopearl HW-65 TOSOH Co., Ltd., DEAE-Sepharose CL-6B (Pharmacia Fine Chemicals), and Bio-Gel P-100 (Bio Rad Laboratories) were obtained from commercial sources. If not stated, other chemicals were purchased from commercial sources.

Analytical methods. The concentration of the enzyme was measured spectrophotometrically on the basis that $E_{1}^{1 \%} \mathrm{~cm}$ at $280 \mathrm{~nm}$ was 14.4 , which was obtained from the relation between the amount of protein measured by the procedure of Lowry et al. ${ }^{201}$ and absorbance at $280 \mathrm{~nm}$ of the purified enzyme preparation.

The enzyme reaction mixture, consisting of $0.5 \mathrm{ml}$ of $0.5 \%$ substrate, $0.4 \mathrm{ml}$ of $0.1 \mathrm{M}$ sodium acetate buffer $(\mathrm{pH}$ 5.0 ), and $0.1 \mathrm{ml}$ of enzyme solution was incubated at $37^{\circ} \mathrm{C}$ for $5 \mathrm{~min}$. Liberated reducing sugar was measured by the Somogyi-Nelson methods. ${ }^{21,22)}$ One unit of enzyme activity was defined as the amount of enzyme which produced $1 \mu \mathrm{mol}$ of reducing sugar as fructose or hydrolyzed $1 \mu \mathrm{mol}$ of sucrose per min under the above conditions.

Polyacrylamide gel disc electrophoresis. Disc Electrophoresis ${ }^{23}$ in $7.5 \%$ polyacrylamide gel was done in Tris-glycine buffer ( $\mathrm{pH} 8.3$ ) at a current of $1 \mathrm{~mA}$ per tube $(0.5 \times 7 \mathrm{~cm})$ at $4^{\circ} \mathrm{C}$. Sodium dodecyl sulfate (SDS)-disc electrophoresi ${ }^{24)}$ was done in $0.1 \mathrm{M}$ sodium phosphate buffer ( $\mathrm{pH} 7.2$ ) containing $0.1 \%$ SDS with a current of $8 \mathrm{~mA}$ per tube $(0.5 \times 10 \mathrm{~cm})$ for $5 \mathrm{hr}$ at $4^{\circ} \mathrm{C}$. Protein was stained with Coomassie Brilliant Blue G-250. Isoelectric focusing was done with a Phast System apparatus with Phast Gel IEF 3-9 media containing Pharmalyte carrier ampholyte (Pharmacia Fine Chemicals).

Paper chromatography. Paper chromatography (PC) was done by a multiple ascending technique (triple development) on Toyo Roshi No. 51 filter paper. The solvent system was 1-propanol-ethyl acetate-water $(7: 1: 2)$. The sugars were detected with anisidine phosphate reagent. ${ }^{25)}$

\section{RESULTS}

\section{Purification of inulinase}

All operations were done at 0 to $5^{\circ} \mathrm{C}$ throughout the purification steps.

Step 1. Chromatography on a DEAESepharose CL-6B column. The culture broth (5 1) was filtered to remove mycelia. The filtrate was concentrated by ultrafiltration (Minitan, Millipore Ltd.), then the enzyme solution was dialyzed against $0.01 \mathrm{~m}$ sodium acetate buffer (pH 5.0). The dialysate $(1800 \mathrm{ml})$ was put on a column $(1.6 \times 30 \mathrm{~cm})$ of DEAE-Sepharose CL$6 \mathrm{~B}$ equilibrated with $0.01 \mathrm{M}$ sodium acetate buffer ( $\mathrm{pH}$ 5.0). After removal of nonadsorbed protein, the elution was done with a linear gradient from 0 to $0.3 \mathrm{M} \mathrm{NaCl}$ in the same buffer (Fig. 1). The active fractions (Nos. 111 and 112) were combined.

Step 2. Chromatography on a Toyopearl $H W-65$ column. The enzyme solution $(40 \mathrm{ml})$ obtained in Step 1 was dialyzed against $0.1 \mathrm{M}$ sodium acetate buffer $(\mathrm{pH} 5.0)$ saturated to $40 \%$ with $\left(\mathrm{NH}_{4}\right)_{2} \mathrm{SO}_{4}$ over night. The enzyme solution was put on a column $(1.6 \times 30 \mathrm{~cm})$ of

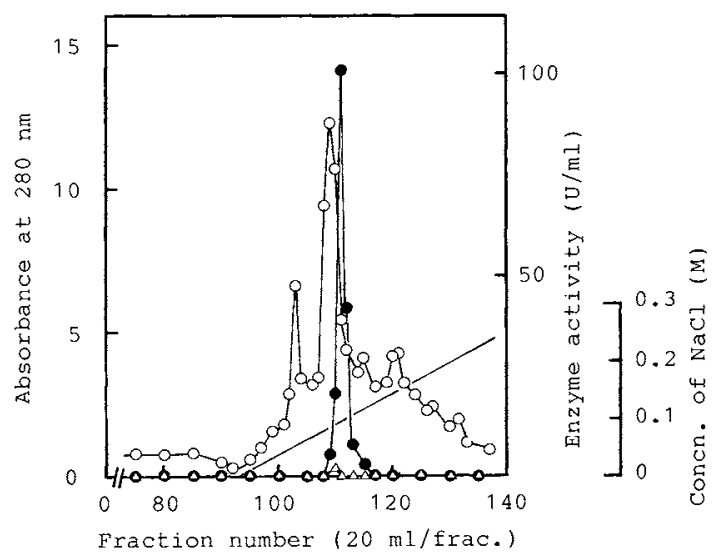

FIG. 1. Chromatography of endo-Type Inulinase from Penicillium purpurogenum on DEAE-Sepharose CL-6B Column.

The enzyme $(1,800 \mathrm{ml})$ was put on a column $(1.6 \times 30 \mathrm{~cm})$ of DEAE-Sepharose CL-6B equilibrated with $0.01 \mathrm{~m}$ sodium acetate buffer ( $\mathrm{pH} 5.0$ ). The elution was done with a linear gradient of $\mathrm{NaCl}$ in the same buffer at a flow rate of $40 \mathrm{ml} / \mathrm{hr}$. - O-, absorbance at $280 \mathrm{~nm} ;-\mathrm{O}$ - inulinase activity; $-\triangle \longrightarrow$, invertase activity; - . concentration of $\mathrm{NaCl}$. 


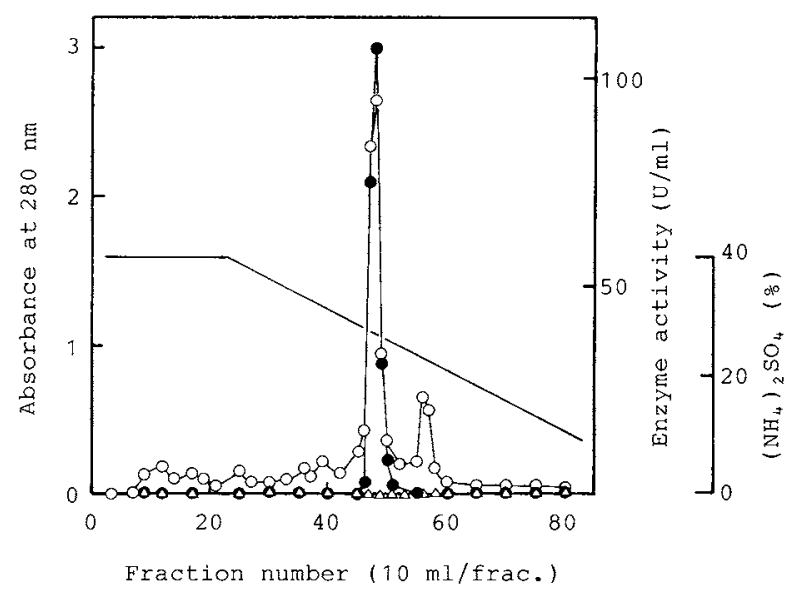

FIG. 2. Chromatography of endo-Type Inulinase from Penicillium purpurogenum on Toyopearl HW-65 Column.

The enzyme $(40 \mathrm{ml})$ was put on a column $(1.6 \times 30 \mathrm{~cm})$ of Toyopearl HW-65 equilibrated with $0.1 \mathrm{M}$ sodium acetate buffer ( $\mathrm{pH} \mathrm{5.0)}$ saturated to $40 \%$ with $\left(\mathrm{NH}_{4}\right)_{2} \mathrm{SO}_{4}$. The elution was done with a linear gradient of $\left(\mathrm{NH}_{4}\right)_{2} \mathrm{SO}_{4}$ in the same buffer at a flow rate of $10 \mathrm{ml} / \mathrm{hr}$.

$-\mathrm{O}-$, absorbance at $280 \mathrm{~nm}$; - - , inulinase activity; $-\triangle-$, invertase activity; - , concentration of $\left(\mathrm{NH}_{4}\right)_{2} \mathrm{SO}_{4}$.

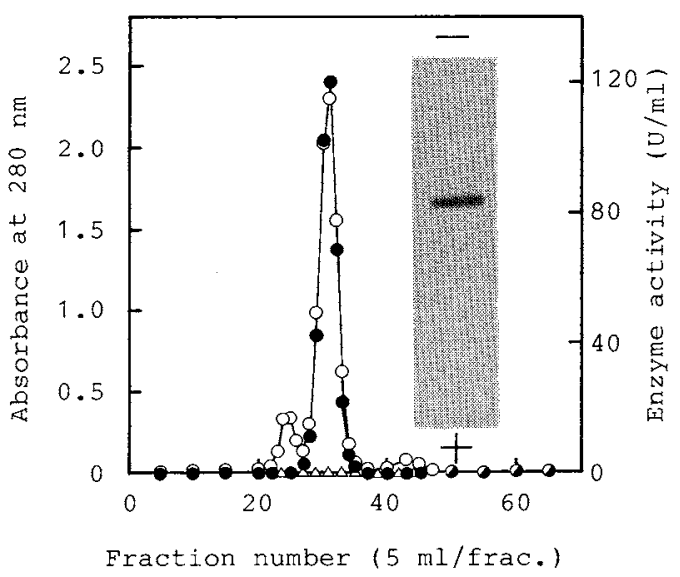

FIG. 3. Gel Filtration of endo-Type Inulinase from Penicillium purpurogenum on Bio-Gel P-100 Column.

The enzyme $(2 \mathrm{ml})$ was filtered on a column $(3.0 \times 65 \mathrm{~cm})$ of Bio-Gel P-100 equilibrated with $0.05 \mathrm{M}$ sodium acetate buffer containing $0.1 \mathrm{M} \mathrm{NaCl}$ and $2 \mathrm{~mm} 2$-mercaptoethanol (pH 5.0), and eluted with the same buffer at a flow rate of $5 \mathrm{ml} / \mathrm{hr}$. - $\mathrm{O}-$, absorbance at $280 \mathrm{~nm} ;--$ - inulinase activity; $-\triangle-$, invertase activity.

Toyopearl HW-65 equilibrated with the same buffer. After removal of non-adsorbed protein, the elution was done with a linear gradient from 40 to $0 \%\left(\mathrm{NH}_{4}\right)_{2} \mathrm{SO}_{4}$ in the same buffer (Fig. 2). The active fractions (Nos. $47 \sim 49$ ) were combined.

Step 3. Chromatography on a Bio-Gel P100 column. The enzyme solution $(30 \mathrm{ml})$ obtained in Step 2 was concentrated to $2 \mathrm{ml}$ by a collodion bag and then filtered on a Bio-Gel P100 column $(3.0 \times 63 \mathrm{~cm})$ equilibrated with $0.05 \mathrm{M}$ sodium acetate buffer containing $0.1 \mathrm{M}$ $\mathrm{NaCl}$ and $2 \mathrm{~mm}$ 2-mercaptoethanol (pH 5.0) (Fig. 3). The eluates of fractions 30 and 31 were pooled and used as a purified enzyme preparation. The purification procedures of inulinase are summarized in Table I.

The purified inulinase was confirmed to be homogeneous by polyacrylamide gel disc electrophoresis. As shown in Fig. 3, the enzyme migrated as a single protein band.

\section{Estimations of molecular weight and isoelectric point}

The enzyme was electrophoresed on SDSdisc gel and was filtered on Bio-Gel P-150. The molecular weight was estimated to be $6.4 \times$ $10^{4}$, which was nearly the same as the molecular weight of inulinases ${ }^{18)}$ from Penicillium sp.-1 (P-II, $6.35 \times 10^{4}$; P-III, $6.6 \times 10^{4}$ ). The molecular weights obtained by the two methods agreed well with each other. These re- 
Table I. Summary of Purification Procedure of endo-Type Inulinase from Penicillium purpurogenum

\begin{tabular}{|c|c|c|c|c|c|c|c|}
\hline \multirow{2}{*}{ Procedure } & \multirow{2}{*}{$\begin{array}{l}\text { Total } \\
\text { protein } \\
\text { (mg) }\end{array}$} & \multirow{2}{*}{$\begin{array}{l}\text { Total activity } \\
\text { for inulin } \\
\text { (units) }\end{array}$} & \multicolumn{2}{|c|}{$\begin{array}{l}\text { Specific activity } \\
\text { (units/mg) }\end{array}$} & \multirow{2}{*}{$\mathrm{I} / \mathrm{S}$} & \multirow{2}{*}{$\begin{array}{l}\text { Purification } \\
\text { (-fold) }\end{array}$} & \multirow{2}{*}{$\begin{array}{l}\text { Yield } \\
(\%)\end{array}$} \\
\hline & & & $\begin{array}{l}\text { for } \\
\text { inulin }\end{array}$ & $\begin{array}{c}\text { for } \\
\text { sucrose }\end{array}$ & & & \\
\hline Filtrate & $21,400^{a}$ & 4,450 & 0.21 & 0.004 & 50 & 1 & 100 \\
\hline DEAE-Sepharose CL-6B & $202^{a}$ & 2,850 & 14.1 & 0.049 & 290 & 67 & 64.0 \\
\hline Toyopearl HW-65 & $51.3^{a}$ & 2,130 & 41.5 & 0.022 & 1,890 & 198 & 47.9 \\
\hline Bio-Gel P-100 & $13.4^{b}$ & 1,110 & 82.8 & 0.020 & 4,140 & 394 & 24.9 \\
\hline
\end{tabular}

a These values were calculated under the assumption that $E_{1 \% \mathrm{~cm}}^{1 \%}$ at $280 \mathrm{~nm}$ was 10 .

b The value was calculated on the basis of the fact that $E_{1 \mathrm{~cm}}^{1 \%}$ at $280 \mathrm{~nm}$ was 14.4 . $\mathrm{I} / \mathrm{S}$, the ratio of specific activity for inulin to that for sucrose.
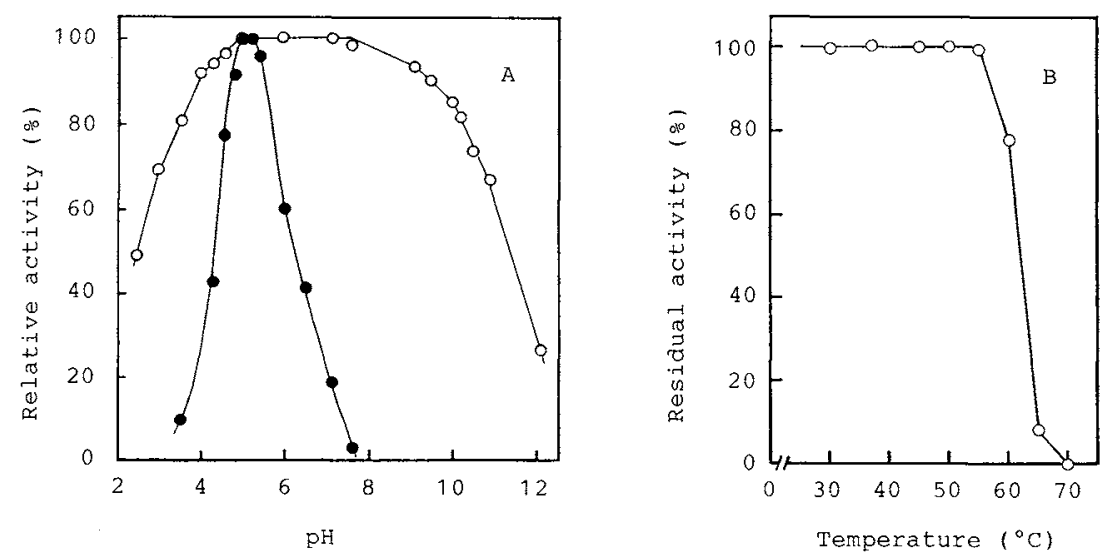

FIG. 4. Effects of $\mathrm{pH}(\mathrm{A})$ and Temperature (B).

$\mathrm{pH}$-Activity curve (- - ) : the reaction mixture containing $0.5 \mathrm{ml} \mathrm{of} 0.5 \%$ inulin, $0.4 \mathrm{ml}$ of BrittonRobinson buffer ${ }^{26)}$ and $0.1 \mathrm{ml}$ of enzyme $(1.71 \mu \mathrm{g})$ was incubated at $37^{\circ} \mathrm{C}$ for $5 \mathrm{~min}$.

pH-Stability curve (-O- ): after the mixture containing $0.02 \mathrm{ml}$ of enzyme $(1.71 \mu \mathrm{g})$ and $0.08 \mathrm{ml}$ of BrittonRobinson buffer had been kept at $4^{\circ} \mathrm{C}$ for $24 \mathrm{hr}, 0.4 \mathrm{ml}$ of $0.2 \mathrm{M}$ sodium acetate buffer (pH 5.1) and $0.5 \mathrm{ml}$ of $0.5 \%$ inulin were added, and the reaction mixture was incubated at $37^{\circ} \mathrm{C}$ for $5 \mathrm{~min}$.

Temperature-stability curve (- - ): after the mixture containing $0.1 \mathrm{ml}$ of enzyme $(1.71 \mu \mathrm{g})$ and $0.4 \mathrm{ml}$ of $0.1 \mathrm{~m}$ sodium acetate buffer $(\mathrm{pH} 5.1)$ had been kept at various temperature for $10 \mathrm{~min}, 0.5 \mathrm{ml}$ of $0.5 \%$ inulin was added, and the reaction mixture was incubated at $37^{\circ} \mathrm{C}$ for $5 \mathrm{~min}$.

sults indicate that there is no subunit structure. The isoelectric point was estimated by isoelectric focusing on a polyacrylamide gel to be $\mathrm{pH}$ 3.6 .

\section{Effects of $p H$ and temperature}

The effects of $\mathrm{pH}$ on inulinase activity were examined. As shown in Fig. 4A, the pH optimum was observed to be 5.1. The enzyme was stable from $\mathrm{pH} 5.0$ to 7.5 . The enzyme was stable up to $55^{\circ} \mathrm{C}$ (Fig. $4 \mathrm{~B}$ ).
Action toward inulin, sucrose, and fructooligosaccharides

Figure 5A shows the courses of the hydrolysis of inulin and sucrose. Inulin was rapidly degraded in the initial phase in the reaction. At $12 \mathrm{hr}$ of reaction, the degree of hydrolysis of inulin was $32.3 \%$, and was scarcely increased afterward. On the other hand, sucrose was nearly unsusceptible to the action of enzyme. The products from inulin were analyzed by PC (Fig. 5B). The major products 

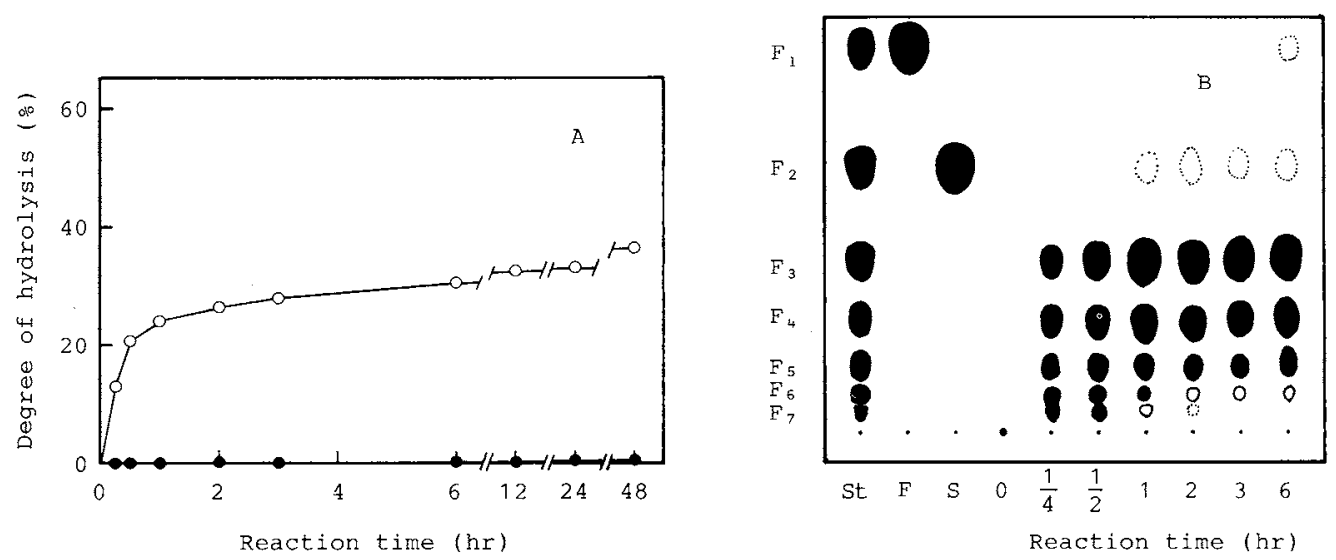

Fig. 5. Time Courses of the Hydrolyses of Inulin and Sucrose (A) and Paper Chromatogram of the Products from Inulin (B) with endo-Type Inulinase from Penicillium purpurogenum.

The reaction mixture containing $6 \mathrm{ml}$ of $0.5 \%$ inulin $(-\mathrm{O}-$ ) or sucrose $(--), 4.8 \mathrm{ml}$ of $0.1 \mathrm{M}$ sodium acetate buffer ( $\mathrm{pH} \mathrm{5.1)}$ and $1.2 \mathrm{ml}$ of enzyme $(20.5 \mu \mathrm{g})$ was incubated at $37^{\circ} \mathrm{C}$. After the indicated times, $0.2 \mathrm{ml}$ of the reaction mixture was pipetted out for measuring the liberated reducing sugar, and $1 \mathrm{ml}$ of the reaction mixture for $\mathrm{PC}$ analysis.

$\mathrm{PC}$ analysis was done as described in MATERials AND METHods. $\mathrm{F}_{1}$, fructose; $\mathrm{F}_{2}$, inulobiose; $\mathrm{F}_{3}$, inulotriose; and through $\mathrm{F}_{7} . \mathrm{St}$, standard; $\mathrm{F}$, fructose; $\mathrm{S}$, sucrose.

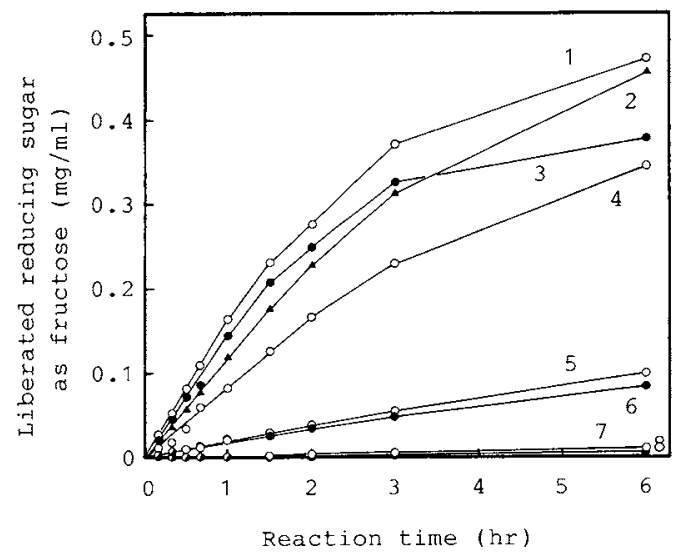

FIG. 6. Time Courses of the Hydrolyses of Fructooligosaccharides with endo-Type Inulinase from Penicillium purpurogenum.

For $1,2,3$, and 4 , the reaction mixture containing $1 \mathrm{ml}$ of $0.5 \%$ substrate, $0.8 \mathrm{ml}$ of $0.1 \mathrm{M}$ sodium acetate buffer $(\mathrm{pH}$ $5.1)$ and $0.2 \mathrm{ml}$ of enzyme $(0.28 \mu \mathrm{g})$ was incubated at $37^{\circ} \mathrm{C}$. At the indicated times, $0.1 \mathrm{ml}$ of the reaction mixture was pipetted out for the determining the liberated reducing sugar.

For $5,6,7$, and 8 , the reaction mixture containing $3 \mathrm{ml}$ of $0.5 \%$ substrate, $2.4 \mathrm{ml}$ of $0.1 \mathrm{~m}$ sodium acetate buffer $(\mathrm{pH}$ $5.1)$ and $0.6 \mathrm{ml}$ of enzyme $(0.84 \mu \mathrm{g})$ was incubated at $37^{\circ} \mathrm{C}$. At the indicated times, $0.5 \mathrm{ml}$ of the reaction mixture was pipetted out. $\mathrm{GF}_{n}, 1^{\mathbf{F}}(1-\beta \text {-D-fructofuranosyl })_{n-1}$ sucrose $(n=2$ to 7 and $\bar{n}=9)$. $1, \mathrm{GF}_{7}(O) ; 2$, inulin $(\mathbf{\Delta}) ; 3, \mathrm{GF}_{\overline{9}}$

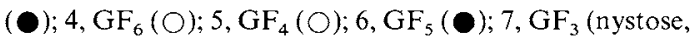
O); $8, \mathrm{GF}_{2}$ (1-Kestose, $)$. were identified at tri-. tetra-, penta-, and hexasaccharides. These results indicates the enzyme attacks inulin endo-wise. In the final phase of the reaction, penta- and hexa-saccharides were hydrolyzed by slow degrees and not only tri- and tetra-saccharides but also a small amount of mono- and di-saccharides were produced. Figure 6 shows the courses of hydrolysis of fructo-oligosaccharides $\left[1^{\mathrm{F}}(1-\beta-\mathrm{D}-\right.$ fructofuranosyl $)_{n-1}$ sucrose, $\mathrm{GF}_{n} ; n=2$ to 7 and $\bar{n}=9$ ]. The inulinase was capable of hydrolyzing $\mathrm{GF}_{6}, \mathrm{GF}_{7}$ and $\mathrm{GF}_{\overline{9}}$ as well as inulin. On the other hand, $\mathrm{GF}_{4}$ and $\mathrm{GF}_{5}$ were hydrolyzed more slowly, $\mathrm{GF}_{3}$ (nystose) and $\mathrm{GF}_{2}$ (1-kestone) were nearly unsusceptible to the action of the enzyme. The characteristics of the action of inulinase from Penicillium purpurogenum reasonably explained the results from $\mathrm{PC}$ analysis.

\section{Rate parameters on hydrolyses of inulin and fructo-oligosaccharides}

The hydrolytic activities at various concentrations of substrates, inulin and fructooligosaccharides $\left(\mathrm{GF}_{n}, n=2\right.$ to 7 and $\left.\bar{n}=9\right)$ were examined. Figure 7 shows the relationship between the initial velocity $(v)$ and the 

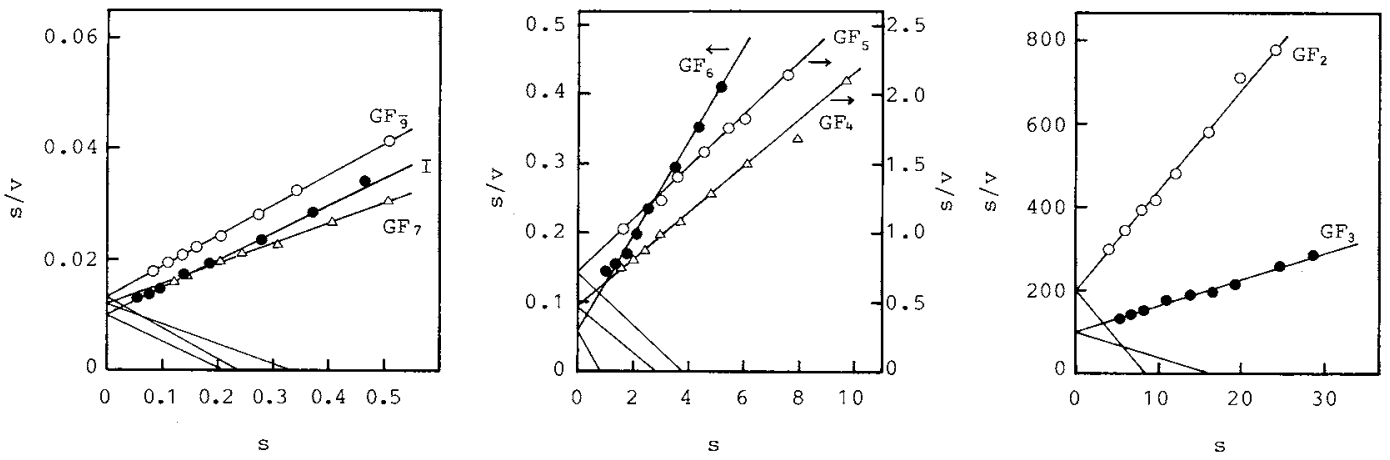

Fig. 7. $s / v$ versus $s$ Plots for Hydrolyses of Inulin and Fructo-oligosaccharides by endo-Type Inulinase from Penicillium purpurogenum.

The reaction mixture containing $0.35 \mathrm{ml}$ of substrate at various concentrations, $0.1 \mathrm{ml}$ of $0.2 \mathrm{M}$ sodium acetate buffer $\left(\mathrm{pH} 5.1\right.$ ) and $0.05 \mathrm{ml}$ of enzyme (inulin, $\mathrm{GF}_{\overline{9}}, \mathrm{GF}_{7}$ and $\mathrm{GF}_{6}, 0.51 \mu \mathrm{g} ; \mathrm{GF}_{5}$ and $\mathrm{GF}_{4}, 1.03 \mu \mathrm{g} ; \mathrm{GF}_{3}$, $13.5 \mu \mathrm{g} ; \mathrm{GF}_{2}, 25.9 \mu \mathrm{g}$ ) was incubated at $37^{\circ} \mathrm{C} . s, \mathrm{~mm} ; v$, mg of reducing sugar as fructose $/ \mathrm{mg}$ of protein $/ \mathrm{min}$. I, inulin. $\mathrm{GF}_{n}, 1^{\mathrm{F}}(1-\beta \text {-D-fructofuranosyl })_{n-1}$ sucrose $(n=2$ to 7 and $\bar{n}=9)$.

Table II. Rate Parameters of endo-Type Inulinase from Penicillium purpurogenum

\begin{tabular}{lccccc}
\hline Substrate & $K m^{a}$ & & $V^{b}$ & $k_{0}{ }^{c}$ & $k_{0} / \mathrm{Km}^{d}$ \\
\hline Inulin & 0.21 & 20.8 & $(100)$ & 123 & 586 \\
Fructo-oligosaccharide & & & & & \\
$\mathrm{GF}_{\overline{9}}$ & 0.24 & 18.0 & $(86.5)$ & 107 & 446 \\
$\mathrm{GF}_{7}$ & 0.33 & 27.5 & $(132)$ & 163 & 494 \\
$\mathrm{GF}_{6}$ & 0.85 & 14.8 & $(71.2)$ & 87.6 & 103 \\
$\mathrm{GF}_{5}$ & 3.8 & 5.29 & $(25.4)$ & 31.3 & 8.2 \\
$\mathrm{GF}_{4}$ & 2.8 & 5.98 & $(28.8)$ & 35.4 & 12.6 \\
$\mathrm{GF}_{3}$ (nystose) & 16 & 0.16 & $(0.8)$ & 0.95 & 0.06 \\
$\mathrm{GF}_{2}$ (1-kestose) & 8.4 & 0.042 & $(0.2)$ & 0.25 & 0.03 \\
\hline
\end{tabular}

a $\mathrm{mM}$.

${ }^{b} \mathrm{mg}$ of reducing sugar as fructose $/ \mathrm{mg}$ of protein $/ \mathrm{min}$. The values in parentheses indicate the relative $V$.

c $\sec ^{-1}$. Molecular activity is expressed as $V / e_{0}$, where $V$ is the mole of the maximum velocity and $e_{0}$ is the mole of enzyme.

d $\mathrm{sec}^{-1} \cdot \mathrm{mM}^{-1}$.

$\mathrm{GF}_{n}, 1^{\mathrm{F}}(1-\beta \text {-D-fructofuranosyl })_{n-1}$ sucrose $(n=2$ to 7 and $\bar{n}=9)$.

substrate concentration $(s)$ for each substrate in $s / v$ versus $s$ plots. The Michaelis constants $(\mathrm{Km})$ and relative maximum velocities $(\mathrm{Rel} \mathrm{V})$ were as follows: inulin $0.21 \mathrm{~mm}$ and $100 ; \mathrm{GF}_{\overline{9}}$ $0.24 \mathrm{~mm}$ and $86.5 ; \mathrm{GF}_{7} 0.33 \mathrm{~mm}$ and $132 ; \mathrm{GF}_{6}$ $0.85 \mathrm{~mm}$ and $71.2 ; \mathrm{GF}_{5} 3.8 \mathrm{~mm}$ and $25.4 ; \mathrm{GF}_{4}$ $2.8 \mathrm{~mm}$ and $28.8 ; \mathrm{GF}_{3}$ (nystose) $16 \mathrm{~mm}$ and 0.8 ; $\mathrm{GF}_{2}$ (1-kestose) $8.4 \mathrm{~mm}$ and 0.2 . In Table II are summarized the rate parameters, $K m, V$, molecular activity $\left[k_{0}\left(=V / e_{0} ; e_{0}\right.\right.$, enzyme concentration) calculated from the $V$ value and the molar concentration of the enzyme], and $k_{0} / K m$, for these substrates.

\section{DISCUSSION}

An endo-type inulinase from Penicillium purpurogenum was highly purified. The enzyme showed high activity toward inulin but nearly none toward sucrose. Nakamura and Nakatsu ${ }^{18)}$ reported that inulinases (P-I, -II, and -III) from Penicillium sp.-1 could hydrolyze sucrose as well as inulin, and attacked inulin exo-wise. The enzyme obtained by us was clearly distinguished from those enzymes by reaction mode for inulin.

As for endo-type inulinases from molds, it 


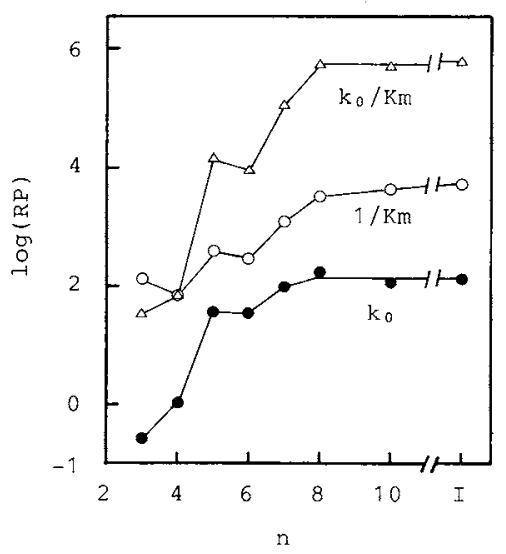

FIG. 8. Dependence of Rate Parameters (RP) on the Degree of Polymerization $(n)$ of Fructo-oligosaccharides. $k_{0}, \mathrm{sec}^{-1} ; K m, \mathrm{M} ; \mathrm{I}$, inulin.

has been reported that Aspergillus niger-12 ${ }^{17}$ ) and Aspergillus ficuum ${ }^{27}$ formed such enzymes. The endo-type inulinase from Penicillium purpurogenum had a resemblance to one of the enzymes from Aspergillus niger-12 (P-III) in its reaction mode for inulin. Both enzymes hydrolyzed inulin rapidly, and much tri-, tetra-, penta-, and hexa-saccharide was produced from inulin. But the Michaelis constants for the hydrolysis of inulin were different from each other.

As shown in Table II, the substrate specificity of endo-type inulinase from Penicillium purpurogenum was studied in detail. The enzyme could hydrolyze fructo-oligosaccharides $\left[1^{\mathrm{F}}(1-\beta \text {-D-fructofuranosyl })_{n}\right.$ sucrose $\quad(n=5,6$ and $\bar{n}=8)$ as well as inulin. The $k_{0}$ values were reduced according to the decrease of the degree of polymerization (DP), if the DP of fructo-oligosaccharides were under seven. The $\mathrm{Km}$ values were also depend on the DP of fructo-oligosaccharides.

In amylases, ${ }^{28 \sim 30)}$ the $\log k_{0}$ values of an enzyme show a characteristic dependence on the DP of malto-oligosaccharides, and the facts are considered to indicate that the active site of the enzyme is made up of the intrinsic subsite structure. ${ }^{28.31)}$ Figure 8 shows the rate parameters on the DP of fructooligosaccharides. The $\log k_{0}$ values of endotype inulinase from Penicillium purpurogenum were also depend on the DP of fructooligosaccharides, if the DP of fructo-oligosaccharides were under seven, although the $\log k_{0}$ values were nearly constant when the DP was seven or more. These results strongly suggest that the active site of endo-type inulinase from Penicillium purpurogenum also has a subsite structure consisting of seven subsites, at least.

\section{REFERENCES}

1) N. Shiomi, J. Yamada and M. Izawa, Agric. Biol. Chem., 40, 567 (1976).

2) N. Shiomi, J. Yamada and M. Izawa, Agric. Biol. Chem., 43, 1375 (1979).

3) N. Shiomi, Phytochemistry, 20, 2581 (1981).

4) N. Shiomi and M. Izawa, Agric. Biol. Chem., 44, 603 (1980).

5) N. Shiomi, Carbohydr. Res., 96, 281 (1981).

6) N. Shiomi, Carbohydr. Res., 99, 157 (1982).

7) N. Shiomi, H. Kido and S. Kiriyama, Phytochemistry, 24, 695 (1985).

8) S. Onodera and N. Shiomi, Abstracts of Papers, the Annual Meeting of Hokkaido Branch of Agricultural Chemical Society of Japan, Sapporo, Dec., 1986, p. 3.

9) T. Yasuda, S. Onodera and N. Shiomi, Abstracts of Papers, the Annual Meeting of Hokkaido Branch of Agricultural Chemical Society of Japan, Sapporo, July, 1987, p. 5.

10) J. Edelman and T. G. Jefford, Biochem. J., 93, 148 (1964).

11) A. E. Flood, P. P. Rutherford and E. W. Weston, Nature, 214, 1049 (1967).

12) P. P. Rutherford and A. C. Deacon, Biochem. J., 126, 569 (1972).

13) R. Dedonder, Bull. Soc. Chim. Biol., 34, 157 (1952).

14) T. Nakamura and S. Hoashi, Nippon Nögeikagaku Kaishi, 43, 599 (1969).

15) H. Negoro and E. Kito, J. Ferment. Technol., 51, 103 (1973).

16) D. G. Derycke and E, J. Vanamme, J. Chem. Technol. Biotechnol., 34, 45 (1984).

17) T. Nakamura, T. Kurokawa, S. Nakatsu and S. Ueda, Nippon Nögeikagaku Kaishi, 52, 159 (1978).

18) T. Nakamura and S. Nakatsu, Nippon Nögeikagaku Kaishi, 51, 681 (1977).

19) S. Morita, H. Tamatani, K. Takahashi, F. Yoshimi, T. Suzuki and K. Sato, Mitsui Toatsu Chemical Co., Ltd., Japan Kokai Tokkyo Koho, 87,228,293 (Oct. 7, 1987).

20) O. H. Lowry, N. J. Rosebrough, A. L. Farr and R. J. Randall, J. Biol. Chem., 193, 265 (1951).

21) M. Somogyi, J. Biol. Chem., 195, 19 (1952). 
22) N. Nelson, J. Biol. Chem., 153, 375 (1944).

23) R. A. Reisfelt, U. J. Lewis and D. E. Williams, Nature, 195, 281 (1962).

24) K. Weber and M. Obsorn, J. Biol. Chem., 244, 4406 (1969).

25) S. Mukherjee and H. C. Srivastava, Nature, 169, 330 (1952).

26) H. T. S. Britton and R. A. Robinson, J. Chem. Soc., 1931, 458.

27) M. Ettalibi and J. C. Baratti, Appl. Microbiol.
Biotechnol., 26, 13 (1987).

28) K. Hiromi, Biochem. Biophys. Res. Commun., 40, 1 (1970).

29) Y. Nitta, M. Mizushima, K. Hiromi and S. Ono, $J$. Biochem., 69, 567 (1971).

30) S. Iwasa, H. Aoshima, K. Hiromi and H. Hatano, $J$. Biochem., 75, 969 (1974).

31) K. Hiromi, Y. Nitta, C. Numata and S. Ono, Biochim. Biophys. Acta, 302, 362 (1973). 